\title{
MAKNA DAN FUNGSI UPACARA ADAT NYANGKU BAGI MASYARAKAT PANJALU
}

\author{
Oleh \\ Heri Jauhari \\ Universitas Islam Negeri Sunan Gunung Djati Bandung \\ Heri.Jauhari@ymail.com
}

\begin{abstract}
Abstrak
Panjalu sebuah desa bekas kerajaan masyarakatnya sampai sekarang masih memegang tradisi upacara adat nyangku. Masyarakat Panjalu menganggap tradisi tersebut sakral karena berhubungan dengan asal keberadaan dan penyebaran agama Islam di kerajaan Panjalu dan tatar Priangan. Acara inti upacara adat nyangku cermah keagamaan (Islam), pemberesiahan benda-benda pusaka, dan beberapa rangakaian acara lainnya. Secara teoretis tradisi tersebut berhubungan secara ekstrinsik dengan masyarakat pemiliknya, maka akan berfungsi dan bermakna. Penelitian menggunakan metode deskriptif interpretatif. Adapun datanya diperoleh dari obsevasi lapangan. Analisis data menggunakan teori strultural genetik, hermeunetik, dan antropologi. Hasil analisis data menemukan bahwa upcara adat nyangku berfungsi ritual, sosial, pendidikan, dan wisata religi. Dari keempat fungsi itu, fungsi ritual yang paling dominan. Selanjutnya upacara adat nyangku bermakna literal/historis, alegoris, tropologis/ moral/pendidikan, dan anagogis. Dari keempat makna tersebut, makna historis intensitasnya paling tinggi.

Kata kunci: nyangku, fungsi, makna, upacara adat
\end{abstract}

Panjalu is a village served as a capital of a kingdom whose society still maintained a tradition called nyangku. The Panjalu people see the custom as a sacred tradition since it has been closely related to their exegesis of Islam in the Kingdom of Panjalu and the Priangan. The core of ritual ceremony is Islamic preaching, heirlooms cleansing, and some others. The tradition has theoretically an extrinsic relation to the people; hence it has functions and serves some meanings. The research employed descriptive interpretative method whose data were retrieved from field observations. The data analysis used genetic-structuralist, hermeunetics, and anthropology theory. The results showed that the nyangku tradition functions as ritual, social, education and religious tourism. Of the four functions, the ritual is the most dominant function. Other than that, the nyangku ritual has literal/historical, moral/didactive, and anagogical meanings. Out of the four, the historical meaning is the most significantly used.

Key word: nyangku, function, meaning, tradition

\section{A. PENDAhULUAN}

Kebudayaan berhubungan dengan semua kehidupan manusia yang bersifat hubungan subordinatif. Di antara hubungan kedua unsur tersebut ada yang berkedudukan sebagai maine system dan subsystem. Sisitem utamanya kebudayaan dan subsistemnya semua kehidupan manusia yang merupakan produk budaya termasuk folklor. Ratna (2010: 6) mengatakan, "kebudayaan mengolah alam melalui kemampuan akal." Hasil olahan-olahan budaya itu melahirkan jenis-jeni folklor.

Secara etimologi kata folklor berasal dari bahasa Inggris Folklore. Kata itu merupaka gabungan kata folk dan lore yang biasa disebut kata majemuk. Kata folk dipadankan dengan sekelompok masyarakat atau kolektif dan kata lore dipadankan dengan cerita atau tradisi yang diwariskan secara turun-temurun baik berbentuk lisan, setengah lisan, maupun bukan lisan (benda). Secara istilah pengertian folklor 
menurut Danandjaja (2007: 3), " Folklor adalah sebagian kebudayaan suatu kolektif yang tersebar dan diwariskan turun-temurun di antara kolektif macam apa saja, secara tradisional dalam versi yang berbeda, baik bentuk lisan maupun contoh yang disertai dengan gerak isyarat atau alat pembantu pengingat."

Dari segi tipenya folklor dapat digolongkan pada tiga kelompok besar yakni (1) folklor lisan (verbal folklore), (2) folklor sebagian lisan, (Partly verbal folklore), dan (3) folklor bukan lisan (non verbal folklore). Folklor lisan terdiri atas bahasa rakyat, ungkapan tradisional, pertanyaan tradisional, cerita prosa rakyat, dan nyanyian rakyat. Selanjutnya cerita prosa rakyat dibagi tiga lagi yakni mitos (myth), legenda (legend), dan dongeng (folktale). Folklor setengah lisan seperti upacara-upacara adat berupa gerak dan isyarat disertai bacaan mantra. Folklor bukan lisan (benda) berupa bendabenda peninggalan nenek moyang kita seperti artefak, bangunan, makanan, obat-obatan, peralatan, dan lain-lain (Brunvard dalam Danandjaja, 2007: 21-50).

Folklor merupakan bagian dari kebudayaan, maka teori-teori kebudayaan masuk pada teori folklor, khususnya pada folklor lisan atau cerita rakyat. Menurut Brooner (2007: 54)," In Folkloristic writing, the "mirror" concept is still applied to relate historical and cultural information about a group, with the persumption that it is also a marker if a particularistic social identity" (Dalam tulisan bergaya folklor, konsep "cermin" masih diaplikasikan untuk menghubungkan informasi budaya dan sejarah sebuah kelompok, dengan anggapan bahwa ini juga adalah suatu penanda bagi identitas sosial yang sangat khusus). Dengan demikian folklor sebagai informasi cerminan identitas sebuah kelompok masyarakat masa lalau.

Folklor sebagai informasi cerminan sebuah kelompok masyarakat merupakan rekaman tidak-tanduk kehidupan manusia zaman dahulu. Banyak unsur kehidupan manusia terekam baik secara tersurat, maupun tersirat dalam folklor. Propp (1997: 3) mengatakan," None of the humanities, be it ethnography, history, linguistics, or the history of literature, can't do without folklore. Litle by little we are becoming aware that the solution to many diverse phenomena of spiritual culture is hiden in folklore" (Tak satupun dari ilmu humaniora,
Makna dan Fungsi Upacara Adat Nyangku bagi Masyarakat Panjalu

baik itu etnografi, sejarah, linguistik, atau sejarah sastra, dapat berjalan tanpa folklor. Sedikit demi sedikit kita menyadari bahwa solusi bagi fenomena kebudayaan spiritual yang beragam itu tersembunyi dalam folklor). Dengan demikian, kalau kita ingin mengetahui kehidupan masa lalu melalui pesan-pesan yang disampaikan para nenek moyang kita bisa diketahui melalui folklornya.

Panjalu sebuah ibu kota kecamatan yang bersejarah masyarakatnya memunyai berbagai folklor yang menarik dan terpelihara baik folklore lisan, setengah lisan, maupun bukan lisan. Folklor setengah lisan yang terkenal dan terpelihara salahsatunya ritual upacara adat nyangku. Upacara adat nyangku ialah memeringati masuknya agama Islam pertama pada kerajaan Panjalu khusunya dan tatar Priangan umumnya. Upacara adat tersebut diadakan berdasarkan keyakinan atas kebenaran pada cerita Sanghiyang Prabu Borosngora (folklor lisan) mengislamkan kerajaan Panjalu yang tadinya beragama Animisme-Dinamisme. Upacara adat nyangku dilaksanakan setiap tahun di akhir bulan Robiul Awal (Maulid) pada hari Senin atau Jumat oleh yayasan Borosngora dan pemerintah daerah setempat. Upacara adat nyangku biasa dikunjungi oleh orang-orang dari berbagai daerah bukan saja dari daerah sekitar pulau Jawa, tetapi juga dari luar pulau Jawa dengan berbagai kepentingan dan harapannya.

Upacara adat nyangku sudah berlangsung lama secara turun-temurun dari generasi ke generasi dengan aturan dan tatacara yang tetap. Upacara adat ini merupakan kearifan lokal (local wisdom) warisan nenek moyang orang Panjalu yang masih bertahan sampai sekrang. Kearifan lokal ini tidak mungkin diturunkan oleh leluhurnya dan dipertahankan oleh generasi berikutnya secara terus-menerus kalau tidak ada fungsi dan manfaatnya. Fungsi terkandung dalam proses antarhubungan, baik mikro mapun makro. Proses antarhubungan yang pertama terjadi dalam folklor itu sendiri, sebagai antarhubungan intrinsik, sedangkan proses antarhubungan yang kedua terjadi antara folklor dan masyarakat termasuk antarhubungan ekstrinsik (Ratna, 2010: 134). Berdasakan pendapat di atas fungsi yang akan dicari pada penelitian ini fungsi hubungan ekstrinsik antara folklor (upacara adat nyangku) dengan masyarakat pemiliknya.

Setiap hasil kebudayaan memunyai bentuk, fungsi, dan makna baik hasil kebudayaan tertu- 
lis, lisan, setengah lisan, maupun bukan lisan. Sebuah upacara adat sebagai hasil kebudayaan apapun bentuknya apabila difungsikan dalam suatu masyarakat, maka akan menghasilkan makna. Ratna (2010: 119) mengatakan, "Setiap aktivitas kebudayaan berfungsi atau difungsikan secara baik dengan sendirinya memiliki makna." Begitu juga dengan upacara adat nyangku sebagai hasil proses antarhubungan folklor setengah lisan dengan masyarakat sebagai hubungan ekstrinsik mempunyai fungsi dan makna. Masalahnya apa makna upcara adat nyangku di Panjalu dan apa fungsi upcara adat nyngku bagi masyarakat Panjalu.

Penelitian folklor setengah lisan (ritaul upcara adat) telah banyak dilakukan. Dengan demikian, pada bagian ini penulis akan meninjau beberapa hasil penelitian terdahulu yang ada hubungannya dengan penelitian fungsi dan makna ritual upacara adat nyangku di Panjalu yang akan dilakukan. Hal ini dilakukan untuk mengetahui teori/konsep, objek, hasil penelitian, keterkaitan, dan memastikan rencana penelitian yang diusulkan belum ada yang meneliti. Penelitian-penelitian yang ada hubungannya dan relevan dengan penelitian yang akan dilakukan ialah sebagai berikut.

Pertama, Penelitian Madhan Khoiri, tahun 2009 yang berjudul: Makna Simbol dan Pergeseran Nialai Tradisis Upcara Adat Rebo Pungkasan. Penelitian ini meneliti makna simbol dan pergeseran nilai upacara adat Rebo Pungkasan dengan metode deskriptif analisis dan teori semiotika. Adapun hasil penelitiannya bahwa upacara adat Rebo Pungkasan telah mengalami pergeseran nilai yang semula sebagai sarana dakwah penyebaran agama Islam, masyarakat sekarang memaknainyai sebagi sarana hiburan dan aset pariwisata bagi masyarakat Wonokromo.

Kedua, Penelitian Ela Nurmawati, tahun 2010 yang berjudul: Kajian Folklor Upacara Adat Saparan Pundhen Joko Kasihan di Desa Cacaban Kidul Kecamatan Bener Kabupaten Purworejo. Penelitian ini meneliti fungsi upacara adat Saparan Pundhen Joko Kasihan dengan metode deskriptif analisis dan teori semiotika pragmatik. Adapun hasil penelitiant tersebut bahwa folklor Saparan Pundhen Joko Kasihan berfungsi ritual, sosial, dan pelestarian tradisi.

Ketiga, Penelitian Sayyidah Mukharomah, tahun 2011 yang berjudul: Memaknai Upacara
Adat Tamat Sebagai Teks Kebudayaan Studi Kasus pada Masyarakat Desa Kemuja Kecamatan Mendo Barat Kabupaten Bangka. Penelitian ini meneliti pelbagai interpretasi masyarakat terhadp upacara adat Tamat dengan metode deskriptif interpretatifdan Postrukturalis.Hasilnya ada beberapa variasi makna normatif teks upacara adat Tamat pada tetua kampung dan tetua adat, antara lain: syiar Islam agar masyarakat semangat mempelajari Al-Qur'an, dan ujian bagi kemampuan seorang membaca Al Qur'an.

Keempat, Penelitian Maya Nurmayanti, tahun 2014 yang berjudul: Upacara Adat Nyuguh Kampung Kuta di Desa Karangpaningal Kecamatan Tambaksari Kabupaten Ciamis. Objek penelitian saudari Maya Nurmayanti kearifan lokal kapung Kuta, metode deskriptif kualitatif, dan teori strukral semiotik. Adapun hasil penelitia tersebut bahwa makna Upacara Adat Nyuguh diantaranya: menjaga dan melestarikan tradisi turun temurun dari nenek moyang, menyambut datangnya bulan Maulid, sebagai penolak bala, sarana mempererat tali persaudaraan masyarakat kampung Kuta, dan mencari keselamatan agar terhindar dari marabahaya dengan cara mengantarkan utusan Padjajaran menyebrang ke sungai Cijolang dengan selamat tanpa merusak kampung.

Kelima, Penelitian Nadia Karasuta, tahun 2014 yang berjudul: Perilaku Sakral dan Profan pada Upacara Adat Rebo Wekasan di Desa Suci Kabupaten Gresik. Objek kajian penelitian ini fenomena Rebo Wekasan di Desa Suci yang mengalami perubahan dari sakral ke profan, metode kualitatif, dan teori Strukturasi oleh Anthony Giddens. Hasil penelitian menunjukan perubahan yang terjadi pada Rebo Kasan disebabkan adanya kepercayaan air di sendang yang dapat mengobati segala penyakit. Kepercayaan tersebut mengundang pengunjung dan pedagang datang ke Rebo Kasan. Akhirnya pemerintah Desa Suci sebagai dominasi menyadari banyak keuntungan. Rebo Kasan kini justru lebih menonjolkan unsur hiburan dan wisata daripada ritualnya yang sakral.

Hasil-hasil penelitiaan terdahulu di atas, menunjukan ada relevansinya dengan penelitian yang akan dilaksanakan baik dari segi metode, teori, maupun jenis objeknya yakni folklor setengah lisan (upacar adat). Selain itu dengan mengkaji hasil-hasil penelitian terdahulu, maka 
diketahui penelitian yang dilakukan baik dari segi objek maupun masalahnya belum ada yang meneliti. Hal tersebut menunjukan adanya kebaruan dalam penelitian yang dilakukan.

Dengan demikian, bedasarkan latar belakang dan tinjauan pustaka di atas, tujuan penelitian ini bermaksud mengetahui makna dan fungsi upcara adat nyangku bagi masyarakat Panjalu kabupaten Ciamis. Untuk menegtahui makna dan fungsi tersebt, dalam penelitian ini menggunakan teori struktural genetik (Terry Eageton, 1976), hermeunetik (Saint Thomas Aquinas, 2004), dan antropologi (David Kaplan dan Robert A. Manner. 2002).

\section{B. METODE PENELITIAN}

\section{Metode}

Penelitian ini menggunakan dua metode yakni metode etnografi dan metode deskriptif analisis. Metode etnografi digunakan dalam pengumpulan data dengan alur penelitiaan maju bertahap. Langkah-langkah alur maju bertahap menurut Spradley (2006: 63), “ menetapkan informan, mewawancarai informan, membuata catatan etnografis, dan seterusnya. Aktivitasaktivitas ini merupakan langkah-langkah dalam proses alur penelitian maju bertahap (The Development Researc Squence) yang lebih luas." Metode deskriptif analisis digunakan untuk mendeskripsikan fakta-fakta yang kemudian dianalisis. Hal tersebut tidak sematamata mendeskripsikan atau menguraikan faktafakta melainkan juga memberikan penjelasan dan pemahaman secukupnya (Ratna, 2004:53). Alasan menggunakan metode tersebut, karena cara kerja metode penelitian ini dapat mendeskripsikan ritual upcara adat yang dilakulan oleh rakyat Panjalu untuk diinterprestasikan fungsi dan maknanya.

\section{Sumber Data}

Sumber data penelitian ini terdiri atas sumber data primer dan sumber data sekunder. Sumber data primer ialah ritual upacara adat nyangku yang dilaksanakan oleh masyarakat Panjalu setahun sekali. Sumber data sekunder ialah tututran rakyat Panjalu yang telah ditetapkan sebagai responden (informan) pada prapenelitian di tempat melalui wawancara.

\section{Jenis Data}

Data biasa dipadankan dengan tanda bukti yang dianalisis untuk menjawab pertanyaan
Makna dan Fungsi Upacara Adat Nyangku bagi Masyarakat Panjalu

penelitian (Jauhari, 2010: 38). Jenis data penelitian ini ialah data kualitatif berupa rekaman, foto-foto pelaksanaan upcara adat nyangku, dan tuturan masyarakat panjalu mengenai tersebut yang diperoleh melalui wawancara.

\section{Teknik Pengumpulan Data}

Pengumpulan data menggunakan teknik pengumpulan folklor (Danandjaja, 2007: 191). Pengumpulan data dengan menggunakan metode pengumpulan folklor ada beberapa tahapan yang harus dilalui, tahap-tahap tersebut sebagai berikut.

\section{a. Prapenelitian di tempat}

Tahap prapenelitian di tempat peneliti harus memersiapkan cara mendekati imforman agar mereka mau meceritakan apa yang mereka lakukan. Kemudian menentukan bentuk folklor apa yang akan kita kumpulkan.

\section{b. Penelitian di tempat}

Setibanya di tempat peneliti harus mencari tahu pemilik atau pewaris folklor yang dimaksud. Teknik yang digunakan dalam pengumpulan data (folklor) ini ialah teknik wawancara dan pengamatan (rekaman). Wawancara yang biasa digunakan dalam pengumpulan folklor ada dua yakni wawancara tidak terarah (non directed) dan wawncara terarah (directed). Teknik pengamatan digunakan untuk melihat suatu benda dan peristiwa. Tetapi yang dimaksud pengamatan di sini tidak terbatas pada apa yang dilihat secara visual saja, melainkan termasuk apa yang didengar dan dicium. Hal-hal yang diamati ialah: pertama, lingkungan sosial tempat folklor berada; kedua, para peserta atau pelaku ritual dan informan; ketiga, pelaksanaan atau tatacara upcara adat dilaksanakan.

\section{c. Pengujian kebenaran data wawancara}

Pengujian kebenaran data wawancara: pertama, dengan cara mengecek kepada informan lain dengan daftar pertanyaan yang sama; kedua, dengan melihat kenyataan berdasarkan pengamatan kita sendiri.

\section{Teknik Analisis Data}

Penganalisisan data dilakukan dengan menggunakan teknik analisis data kualitatif. Metode ini memberikan perhatian utama pada makna, dan pesan sesuai dengan hakekat 
objeknya, yaitu sebagai studi kultural (Ratna, 2004: 46). Data- data yang telah terkumpul dianalisis derngan menggunakan teori struktural genetik dan hermeneutik. Adapun langkahlangkah yang ditempuh sebagai berikut.

a. Menentukan fungsi upacara adat nyangku sebagai tata simbolik hasil hubungan ekstrinsik dengan lingkungan sosial tempat upacara adat diciptakan berdasarkan teori struktural genetik.

\section{HASIL DAN PEMBAHASAN}

\section{Kondisi Objektif Wilayah Panjalu}

Berdasarkan hasil pengumpulan data di lapangan baik yang dilakukan dengan cara observasi, pengamatan, maupun wawancara bahwa gambaran umum kecamatan Panjalu sebagai beriklut.

\section{a. Geografi kecamatan Panjalu}

Letak geografi kecamatan Panjalu di dataran tinggi sebelah Utara ibu kota kabupaten Ciamis tepatnya di kaki gunung Syawal. Jarak antara kecamatan Panjalu dengan ibu kota kabupaten Ciamis tiga puluh empat kilo meter. Ciri khas Panjalu udaranya yang dingin dan apabila musim hujan selalu diselimuti kabut sehingga terkenal dengan 'ibun (embun) Panjalu". Tanahnya yang subur dengan daerah berbukit-bukit ditumbuhi pohon-pohon yang lebat menyebabkan banyaknya mata air sebagai salah satu sumber kemakmuran masyarakat Panjalu. Kecamatan Panjalu ke sebelah Utara berbatasan dengan kecamatan Sukamantri, ke Timur berbatasan dengan kecamatan Lumbung, ke Barat berbatasan dengan kecamatan Panumbangan, dan ke Selatan berbatasan dengan gunung Syawal. Kecamatan Panjalu terdiri atas delapan desa yakni desa Panjalu, Ciomas, Sandingtaman, Bahara, Maparah, Kertamandala, Mandalare, dan desa Hujungtiwu.

\section{b. Kondisi Ekonomi, Sosial, dan Agama Masyarakat Panjalu}

Mata pencaharian masyarakat Panjalu pertanian, peternakan, perdagangan, dan usaha di bidang jasa dengan presentase empat puluh persen sebagai petani, empat puluh persen pedagang, lima persen peternak, dan lima belas persen usaha di bidang jasa. Seprti di katakan b. Memaknai kode-kode atau simbol-simbol yang terdapat dalam ritual upcara adat nyangku baik kode bahasa, maupun kode budaya berdasarkan teori struktural genetik dan hermeneutik.

c. Langkah selanjunya yaitu mendeskripsikan hasil penelitian, menarik kesimpulan, dan (3) membuat laporan penelitian.

di atas, letak geografi wilayah Panjalu di dataran tinggi dikelilingi gunung-gunung yang ditumbuhi pohon-pohon lebat menyebabkan banyaknya mata air untuk menyuburkan tanah. Sehubungan dengan banyaknya air, pertanian di Panjalu utamanya penanaman padi. Selain itu, masyarakat Panjalu banyak yang menjadi peternak khusunya beternak ayam potong sehingga Panjalu merupakan salah satu pemasok kebutuha ayam pedaging nasional.

Dalam bidang perdagangan masyarakat Panjalu sangat maju baik yang di daerah Panjalunya sendiri, maupun di luar Panjalu seperti Bandung dan Jakarta. Di kota Bandung orang Panjalu sangat terkenal sebagai pedagang besi tua dan material bahan bangunan. Dalam bidang perdagangan orang Panjalu memunyai beberapa mitos yang tidak boleh dilanggar seperti tidak boleh pergi dari rumah niat berusaha ke tempat lain contohnya ke Bandung pada hari Sabtu dan pada Rabu Kasan. Dalam bidang jasa usaha orang Panjalu kebanyak pada jasa angkutan baik angkutan umum berupa mobil, ojeg, maupun angkutan umum berupa perahu pariwisata. Hal tersebut karena Panjalu terkenal dengan objek wisata Situ Lengkong dengan wisata airnya.

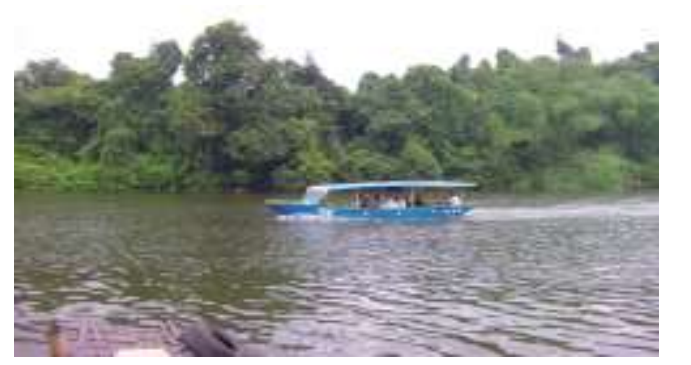

Gambar 1: Wisata air Situ Lengkong Panjalu Sumber: Dokumen pribadi tahun 2014 
Kondisi sosial masyarakat Panjalu masih sangat baik. Kerjasama antarwarga masih berjalan seperti biasa kalau ada warga yang kena musibah, membuat rumah, hajatan, dan kematian mereka saling membantu baik materi, maupun tenaga (moril dan materil). Kebiasaan di Panjalu kalau ada yang hajatan, membangun rumah, kematian, dan kena musibah ibu-ibu membantu dari segi materi seprti menyumbang makanan atau bahan makanan dan bapakbapaknya menyumbang tenaga. Selain itu, pembangunan sarana-sarana umum masih dikerjakan secara gotong-royong.

Kesenian tradisional yang masih bertahan di Panjalu di antaranya karinding, calung, debus, gemyung, dan bebegig. Karinding sebuah alat tiup yang terbuat dari bambu kecil biasa dimainkan oleh anak-anak. Calung alat kesenian yang terbuat dari bambu terutama bambu hitam yang dimainkan dengan cara dipukul dan dimainkan secara berkelompok. Debus seni pertunjukan permainan (kedugalan) yang dimainkan baik secara perseorangan maupun berkelompok dan biasa duhubungkan dengan yang gaib. Gemyung alat kesenian yang terbuat dari tempurung dan kulit kambing yang dimainkan oleh para orang tua dengan cara dipukul secara bersamaan sambil membaca selawat di malam hari. Bebegig manusia berbalut ijuk dan memakai topeng menyerupai ogoh-ogoh di Bali. Selain itu, keseniankesenian tradisional Panjalu selain dimainkan pada acara upacara adat nyangku, biasa dimainkan juga pada acara hajatan-hajatan apabila ada yang mengundang.

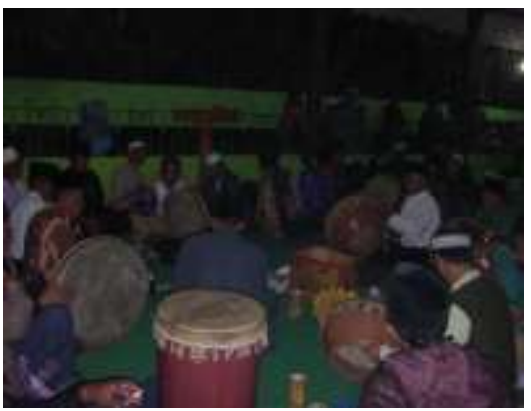

Gambar 2: Pentas seni gemyung

Sumber: Dokumen pribadi tahun 2014

Kesenian tradisional Panjalu yang ada hubungannya dengan cerita Panjalu debus dan gemyung. Seni tradisional debus pada upacara adat nyangku biasa dipertunjukan pada malam hari sebelum upacara adat dilaksanakan. Tempat pertunjukan debus di alun-alun Panjalu yang pagi harinya sebagai tempat upacara adat "nyangku". Gemyung biasa dimainkan oleh para orang tua pada malam hari sampai pagi (menjelang subuh) di "Bumi Alit" sebagai penutup rangkaian acara sebelum upacara adat nyangku dilaksanakan.

Agama masyarakat Panjalu semenjak kerajaan Soko Galuh sampai kerajaan Panjalu yang dipimpin Prabu Cakra Dewa beragama Aimisme-Dinamisme. Setelah Prabu Borosngora beragama Islam kerajaan Panjalu menjadi kerajaan Islam, karena semua keluarga kerajaan masuk Islam dan menjadi penyebar agama Islam di berbagai daerah khusunya di Jawa Barat kecuali ayahandanya Prabu Sanghiyang Cakra Dewa. Maka dari itu, cerita kerajaan Panjalu identik dengan sejarah penyebaran agama Islam di Panjalu khusunya dan Jawa Barat Umumnya. Hal tersebut sama dengan cerita Kian Santang dan cerita Sunan Gunung Djati. Dengan demikian, semenjak itulah masyarakat Panjalu beragama Islam dan sekarang hampir seratus persen beragama Islam, karena dari sekian banyak masyarakat Panjalu hanya ada empat orang yang beragama (beraliran) kepercayaan.

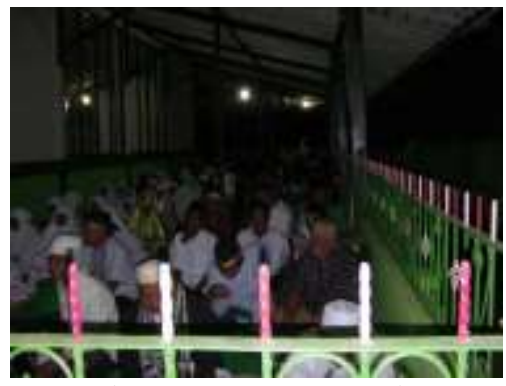

Gambar 3: Masyaakat Panjalu sedang menyimak tablig akbar

Sumber: Dokumen pribadi tahun 2014

\section{c. Eksistensi Folklor dalam Kehidupan Masyarakat Panjalu}

Cerita rakyat di Panjalu intinya hanya ada dua yaitu cerita Prabu Borosngora dan cerita Maung Panjalu. Cerita Prabu Borosngora adalah sejarah Isalamisasi di tatar Priangan khususnya dan Jawa Barat umumnya. Dari cerita Prabu Borosngora lahir dua cerita yakni cerita Hariangkuning-Hariangkencana dan Arisacanata. Kedua cerita ini merupakan bagian dari cerita Prabu Borosngora karena cerita Hariangkuning dan Hariangkencana dua bersaudara putra Prabu Borosngngora yang melanjutkan pimpinan kerajaan Panjalu. 
Selanjutnya Ariasacanata salah satu saudara keturunan Prabu Borosngora yang bukan garis keturunan raja, ketika kerajaan ingin mengangkat raja yang berhak menjadi raja masih kecil, maka dingakatlah raja sementara yaitu Ariasacanata.

Cerita-cerita di atas, hanya ada di desa Panjalu, kecamatan Panjalu. Asalnya kerajaan Panjalu di Dayeuhluhur kemudian oleh Ratu Permana Dewi di pindahkan ke desa Panjalu, sehingga desa Panjalu sebagai pusat kerajaan Panjalu yang terakhir sebelum disatukan dengan kerajaan Imbanagara. Di desa Panjalu kedua cerita itu bertahan karena ketrunan raja Parbu Borosngora adanya di desa Panjalu. Usaha keluarga keturunan kerajaan Panjalu untuk melestarikan cerita, budaya, dan situs peninggalan kerajaan Panjalu membuat sebuah yayasan yang bernama yayasan Borosngora. Mereka setiap tahun mengadakan ritual upacara adat "nyangku" untuk mengenang peristiwa dan melestarikan peninggalan Parbu Borosngora.

Cerita rakyat Panjalu yang sudah dibukukan yaitu ceriat Parbu Borosngora dan Maong Panjalu. Cerita-cerita itu sudah tersimpan di setiap perpustakaan daerah dan diperjualbelikan secara bebas seperti di objek wisata Situ lengkong Panjalu dan di Bumi Alit. Setiap wisatawan yang datang ke Panjalu untuk lebih mengetahui tentang kerajaan Panjalu mereka pada membeli buku cerita tersebut. Selain telah dibukukan, cerita rakyat Panjalu telah diunggah pada internet sehingga siapa saja yang ingin mengetahui cerita Prabu Borosngora tinggal mengunduh "Babad Panjalu" pada Internet.

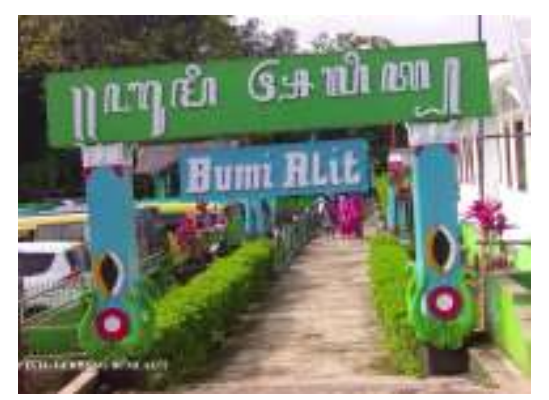

Gambar 4: Gerbang Bumi Alit

Sumber: Dokumen pribadi tahun 2014

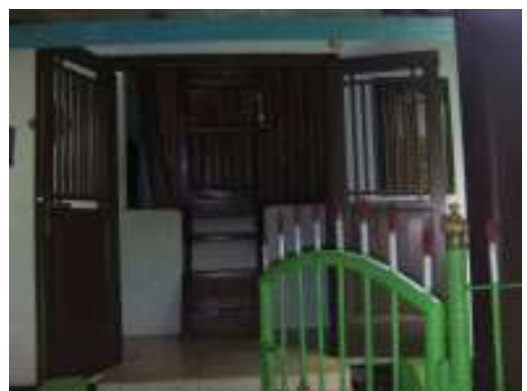

Gambar 5: Bumi Alit tempat menyimpan benda pusaka

Sumber: Dokumen pribadi tahun 2014

Waktu penceritaan cerita rakyat Panjalu. Cerita Prabu Borosngora khususnya diceritakan pada upacara adat nyangku, samida, dan kepada para peziarah. Penyampaian cerita Prabu Borosngora pada acara ritual adat "nyangku" merupakan rangakaian acara tersebut. Penceritaan dilaksanakan pada malam hari setelah pembacaan berjanji sebelum ceramah maulid nabi oleh ketua yayasan. Penceritaan kepada para peziarah baik yang ke makam Hariangkuning di Nusa Geude maupun di Bumi Alit oleh juru kunci (kuncen). Di sekolah-sekolah baik sekolah dasar sampai sekolah menengah atas sekecamatan Panjalu oleh para guru.

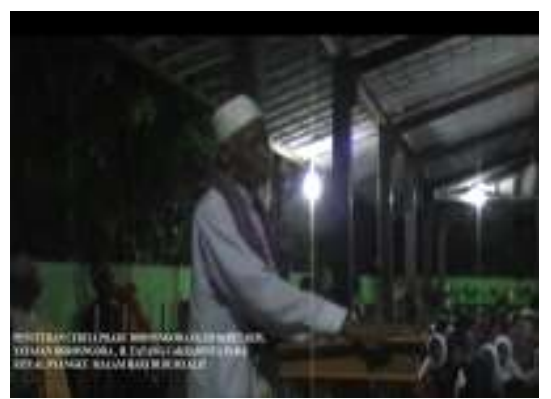

Gamabr 5: Penceritaan cerita Prabu Borosngora oleh ketua yayasan

Sumber: Dokumen pribadi tahun 2014

Penceritaan Maong Panjalu asalnya tidak boleh oleh sembarang orang, kecuali seseorang yang khusus dipercaya sebagai pencerita cerita tersebut. Karena sebelum melakukan penceritaan ada aturan-aturan yang harus dipatuhi terlebih dahulu seperti harus mengadakan ritual yang tidak semua orang dapat melakukannya. Hal tersebut apabila dilanggar mereka percaya pasti ada akibatnya. Tetapi sekarang cerita Maong Panjalu boleh diceritakaan oleh siapa saja dan dimana saja. Di sekolah-sekolah cerita Maong Panjalu biasa 
digunakan sebgai bahan pelajaran muatan lokal (mulok) karena menurut masyarakat Panjalu mengandung pendidikan budi-pekerti.

Usaha yayasan Prabu Borosngora agar cerita rakyat Panjalu bertahan pertama dibukukan, dan kedua dijadikan muatan lokal dalam pendidikan sekolah dasar sampai menengah atas. Hal tersebut sesuai dengan pernytaan kepala UPTD kecamatan Panjalu. Setiap sekolah dasar di kecamatan Panjalu wajib menggunakan cerita Panjalu sebagai bahan pelajaran dan memasukannya pada kurikulum mutan lokal. Selain itu, UPTD menganjurkan kepada semua sekolah dasar sekecamatan Panjalu agar mengikuti upcara adat nyangku yang dilaksnakan di alun-alun Panjlau setahun sekali.

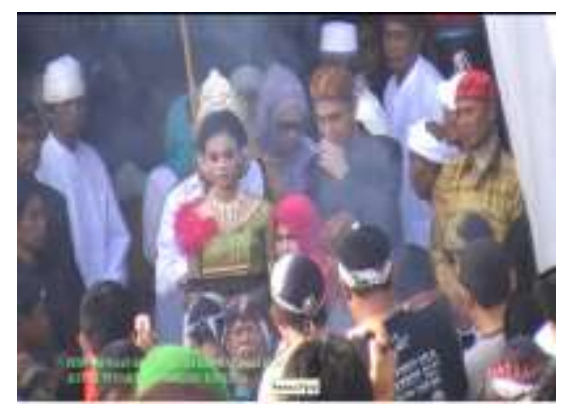

Gambar 6: Masyarakat Panjalu sedang mengikuti upcara adat nyangku

Sumber: Dokumen pribadi tahun 2014

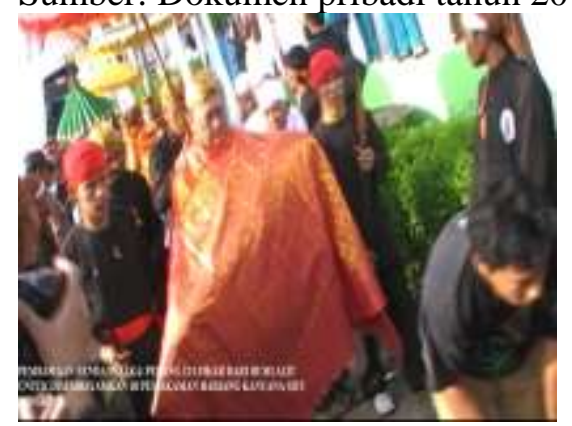

Gambar 7: Pengusungan benda pusaka untuk diberesihkan

Sumber: Dokumen Pribadi tahun 2014

Masyarakat Panjalu yang tahu cerita Prabu Borosngora dan Maong Panjalu sekitar lima puluh persen. Dari lima puluh persen masyarakat Panjalu yang tahu cerita kebanykan para orang tua dan anak-anak sekolah dasar. Bagi para orang tua karena pada zaman dahulu penyebaran cerita rakyat dari mulut ke mulut (leluri) masih berjalan. Bagi para anak sekolah dasar karena sekarang cerita-cerita tersebut telah dijadikan bahan pelajaran sebagai muatan
Makna dan Fungsi Upacara Adat Nyangku bagi Masyarakat Panjalu

lokal. Sedangkan para remaja dan orang dewasa masa kini sudah banyak yang tidak tahu.

\section{d. Cagar Budaya di Kecamatan Panjalu}

Benda-benda cagar budaya yang ada di Panjalu yaitu pedang Syaidina Ali, cis, kujang, bonang, komando, keris, dan lain-lain. Bendabenda tersebut merupakan peninggalan Prabu Borosngora yang biasa diberesihkan setahun sekali pada upcara adat nyangku oleh yayasan Borosngora.

Benda-benda cagar budaya tersimpan di bumi alit. Bumi Alit sebuah bangunan sederhana peninggalan Prabu Borosngora tempat menyimpan benda-benda pusaka. Tetapi sekarang Bumi Alit bukan berarti rumah kecil karena setelah dipugar oleh kelurga keturunan Prabu Borosngora bangunan tersebut menjadi besar dan cukup megah. Sekarang Bumi Alit bukan sekedar tempat penyimpanan bendabenda pusaka, melainkan tempat wisata religi atau berziarah. Setiap hari para peziarah mendatangi Bumi Alit dengan berbagai keperluan dan harapannya sesuai dengan kepercayaannya masing-masing.

Benda-benda pusaka yang tersimpan di Bumi Alit merupakan data dan fakta sejarah kerajaan Panjalu. Benda-benda itulah yang memperkuat kebenaran cerita Prabu Borosngora. Masyarakat Panjalu sangat memercayai kebenaran dan keaslian bendabenda pusaka tersebut peninggalan Prabu Borosngora.

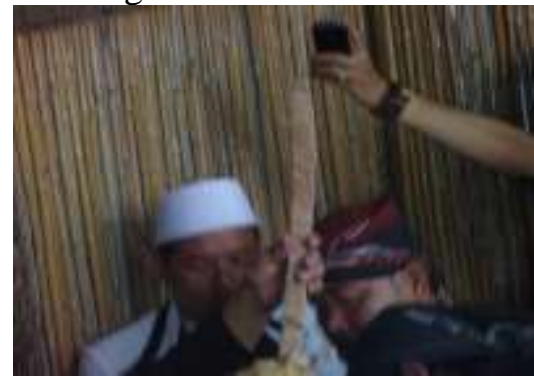

Gambar 8: Benda pusaka pedang Zulfikar sedang dibuka bungkusnya

Sumber: Dokumen pribadi tahun 2014 


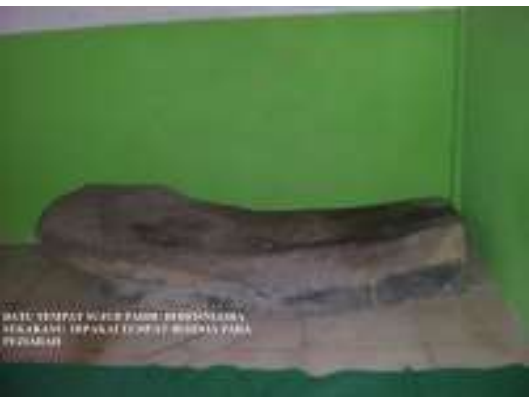

Gambar 9: Batu tempat salat Parabu Borosngora

Sumber: Dokumen Pribadi tahun 2014

\section{e. Kepercayaan, upacara adat, dan Tradisi Masyrakat Panjalu}

1) Kepercayaan Masyrakat Panjalu Cerita rakyat baik cerita Prabu Borosngora, Hariangkuning-Hariangkencana, Ariasacanata, maupun Maong Panjalu sangat dipercayi kebenarannya oleh masyarakat Panjalu. Dimaksud kebenaran di sini, semua peristiwa yang tertera dalam cerita rakyat Panjalu benarbenar telah terjadi. Mereka beralasan bahwa semua peristiwa yang ada dalam cerita telah terjadi karena ada jejaknya atau peninggalannya berupa benda-benda, tempattempat terjadinya peristiwa, dan sebagian ada pemakamannya.

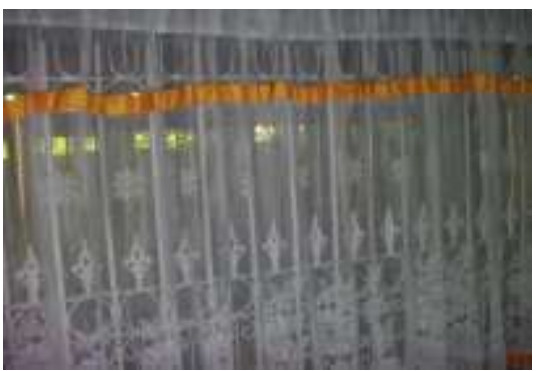

Gambar 10: Makam Hariang Kencana putra Prabu Borosngora

Sumber: Dokumen pribadi tahun 2014

Berdasarkan kepercayaan masyarakat Panjalu terhadap peristiwa masa lalu menyebabkan orang Panjalu melakukan upacara adat nyangku dan samida. Upacara adat nyangku yang dilaksanakan setahun sekali setiap akhir bulan Maulid pada hari Senin atau Jumat maksudnya untuk memperingati dan melanjutkan tradisi yang diwariskan leluhurnya yakni Parbu Borosngora untuk mendapatkan berkat (berkah). Inti yang diperingati pada acara ritual adat nyangku penyebaran agama Islam pertama khusunya di kerajaan Panjalu umumnya di tatar Periangan oleh Parbu Borosngora sekalian memperingati maulid nabi. Adapun acaranya dilaksanakan pada malam hari sambil memperingati maulid nabi dan penceritaan riwayat Prabu Borosngora yang dimeriahkan dengan kesenian tradisional gemyung bertempat di Bumi Alit. Pada siang harinya pencucian benda-benda pusaka yang dipercayai peninggalan Prabu Borosngora dilaksanakan di alun-alun Panjalu setelah disemayamkan terlebih dahulu di pemakaman Nusa Geude.

Samida atau hajat danau Lengkong biasa dilaksanakan setahun sekali seminggu sebelum ritual upcara adat nyangku. Samida asalnya manakib atau pembacaan berjanji dalam kerangka memperingati maulid nabi. Setelah manakib pindah ke pesantren Suryalaya, upacara adat yang biasa dilaksanakan di Lengkong namanya berganti menjadi samida. Inti acara samida pun sama memperingati apa yang telah terjadi di Lengkong Panjalu pada masa lalu.

\section{2) Pelaksanaan Upacara adat Nyangku}

Upacara adat tersebut dilaksanakan di beberapa tempat di Panjalu: pertama, acara penceritaan riwayat Prabu Borosngora, ceramah maulid nabi, dan pentas kesenian tradisional gemyung di Bumi Alit pada malam hari sampai menjelang waktu salat subuh; kedua, pengeluaran benda-benda pusaka dari bumi alit diusung menuju Nusa Geude untuk disemayamkan di pemakaman Hariangkuning pada pagi harinya; ketiga, pencucian benda pusaka di alun-alun Panjalu pada siang hari sampai selesai; dan keempat, mengembalikan benda-benda pusaka ke Bumi Alit. Upacara adat nyangku bukan hanya dihadiri masyarakat dari berbagai daerah, tetapi juga dihadiri para pejabata pemerintah dari tingkat kacamatan sampi tingkat propinsi.

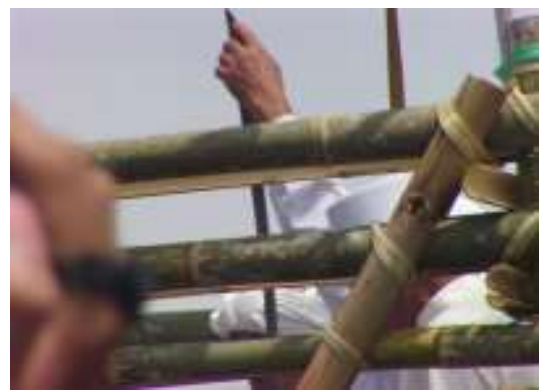

Gambar 11: Ritual pencucian benda pusaka pedang Zulfikar 
Sumber: Dokumen pribadi tahun 2014

Upacara adat samida dilaksanaka seminggu sebelum upcara adat nyangku yang bertempat di Situ Lengkong Panjlau. Pelaksanaan upcara samida ritualnya di Nusa Geude, resepsinya di Nusa Pakel, dan hiburannya di Dermaga. Samida kalau di Pangandaran sama dengan hajat laut, di Panjalu hajat danau (lengkong).

\section{3) Tradisi-tradisi yang Bertahan di Masyarakat Panjalu}

Tradisi-tradisi yang ada di kecamataan Panjalu selain upacara adat nyangku dan samida ialah tradisi pamali. Pamali adalah larangan yang tidak boleh dilanggar oleh orang yang memercayainya, seandainya dilanggar masyarakaat Panjalu percaya pasti ada sankinya. Tradisi pamali ini sangat erat hubungannya dengan kearipan lokal, karena segala sesuatu yang kena tardisi pamali pasti lestari atau bertahan sesuai dengan harapan. Tradisi pamali di Panjalu di antaranya tidak boleh buang air besar atau kecil di Lengkong. Tradisi ini apabila dipatuhi akan menjaga kemurnian atau keberesihan air Lengkong, karena tidak akan terkontaminasi kotoran manusia.

Tradisi selanjutnya hal-hal yang berhubungan dengan cerita Maong Panjalu seperti tidak boleh minum ditotor (tidak dituangkan dahulu pada gelas), makan ketupat harus dibelah, dan tidak boleh makan sayur oyong. Masyarakat Panjalu pada tradisi ini sudah berkurang menaatinya terutama para anak muda, para orang tua masih banyak yang menaatinya. Tradisi ini juga sangat erat kaitannya dengan kearipan lokal terutama menyangkut etika atau pendidikan budi pekerti.

\section{Makna Upacara Adat Nyangku}

Berdasarkan empat kesatuan makana penafsiran hermeunetik ditemukan bahwa upacara adat nyangku bermakna historis/ literal, alegoris, tropologis/moral/pendidikan, anagogis. Dari keempat makna tersebut, makna historis/literal mempunyai intensitas paling tinggi. Karena upacara adat nyangku dilakukan berdasarkan unsur-unsur fakta sejarah yang sangat kuat baik berupa tokoh/pelaku, tempat, peristiwa, mapun benda-benda pusaka. Pelaku utama sejarah Panjalu sebagai berikut: Ratu Garulingsajagat yang kali pertama mendirikan kerajaan Soko Galuh di Dayeu Luhur; Ratu
Makna dan Fungsi Upacara Adat Nyangku bagi Masyarakat Panjalu

Permana Dewi yang memindahkan kerajaan ke Panjalu, Prabu Cakra Dewa penerus kerajaan sekaligus orang tua Sanghiynag Prabu Borosngora. Sayyidina Ali yang mengajarkan agama Islam kepada SPB, dan SPB yang mengislamkan kerajaan Panjalu.

Beberapa tempat sebagai fakta sejarah. Tempat-tempat tersebut sebgai berikut: Dayeuh Luhur tempat kali pertama kerajaan Soko Galuh; Panjalu tempat kerajaan Panjlau; Mekah tempat lahirnya agama Islam; Fadang Arapah tempat pertemuan Sanghiyang Prabu Borosngora dengan Sayyidina Ali; Masjidilharam tempat belajar agama Islam SPB; dan tempat-tempat syiar Islam SPB seperti Sukabumi, Ciasem, Banten, Ciomas, dan Kutai Kartanegara. Tempat-tempat syiar Islam tersebut semuanya mengklaim sebagai tempat akhir hayatnya SPB. Hal tersebut diperkuat oleh cerita Ariasacanata yang mengatakan kerajaan Panjalu merupakan bagian dari kesultanan Cirebon dan kesultanan Cirebon bagian dari kerajaan Majapahit.

Selanjutnya beberapa peristiwa sejarah dalam cerita $S P B$. Peristiwa-peristiwa tersebut sebagai berikut: Prabu Cakra Dewa mengutus SPB untuk mencari ilmu sejati; SPB mendapat ilafat (petunjuk); SPB beguru ilmu sejati (ilmu agama Islam) kepada Sayyidina Ali; SPB memegang kerajaan Panjlau mengganti kakanya Prabu Lembu Sepulur II; SPB mengislamkan kerajaan Panjalu yang tadinya bergama Animisme-Dinamisme; SPB menyebarkan agama Islam di tatar Priangan; dan SPB mengadakan ritual upcara adat nyangku.

Benda-benda peninggalan SPB sebagai fakta sejarah. Benda-benda pusaka peninggalan SPB sebagai fakta sejarah sebgai berikut: pemakaman kelurga kerajaan Panjalu di Nusa Geude; pedang dzukfikar pemberian Sayyidina Ali , cis, kujang, dan batu tempat salat/sujud SPB. Benda-benda tersebut sampai sekarang masih ada di Bumi Alit yang setiap tahun dibersihkan dalam upacara adat nyangku.

Masyarakat Panjalu memercayai keberagamaan mereka berkat perjuangan SPB yang diketahuinya dari cerita leluhurnya (folklor). Dengan demikian, masyarakat Panjalu melakukan upacara adat nyangku untuk memperingati asal mula agama Islam di kerajaan Panjalu khususnya dan tatar Priangan pada umumnya, membersihakan benda-benda pusaka peninggalan Sanghiyang Prabu Borosngora, dan untuk mendapatkan berkat. 


\section{Jurnal al-Tsaqafa Volume 15, No. 02, Desember 2018}

Folklor yang berbentuk legenda sering dipakai untuk merekontruksi sejarah daerah setempat. Legenda yang bisa dipakai merekontruksi sejarah, legenda yang telah diberesihkan dari hal-hal yang bersifat pralogis atau irasionalnya (Danandjaja, 2007: 66). Halhal yang harus dibersihkan pada legenda sebelum dipakai merekonstruksi sejarah ialah sifat-sifat luar biasa tokoh legenda dan peristiwa-peristiwa yang berhubungan dengan mahluk gaib. Menurut Propp (1997: 11), "folklore is a historical phenomenon and the science of folklore, a historical dicipline" (Folklor adalah fenomena historis dan ilmu folklor suatu disiplin ilmu sejarah). Dengan demikian, ilmu folklor dan ilmu sejarah dua disiplin ilmu yang dapat berintegrasi dalam merekonstruksi sebuah sejarah sebab benyak folklor seperti legenda yang didukung oleh fakta-fakat sejarah seperti cerita SPB. Faktafakta itu menyebabkan masyarakat memercayai kebenaran cerita tersebut sehingga mereka mau melaksanakan upcara adat nyangku. Dengan demikian, upacara adat nyangku bermakna historis atau kesejarahan.

\section{Fungsi Upacara Adat Nyangku}

Berdasarkan hasil analisis data dengan menggunakan teori struktural genetik, hermeunetik, dan antropologi sastra, baik data yang diperoleh dari hasil observasi atau pengamatan maupun hasil wawancara ditemukan bahwa upcara adat nyangku di Panjalu berfungsi ritual, sosial, pendidikan dan wisatareligi. Dari keempat fungsi tersebut, fungsi ritual yang paling dominan. Ritual-ritual yang dilaksanakan oleh masyarakat Panjalu pada upacara adat nyangku dilaksanakan atas dasar keyakinan mereka pada kebenaran cerita tersebut dengan harapan mendapatkan berkat. Maka dalam setiap upacara adat salah satu acaranya penceritaan cerita Sanghiyang Prabu Borosngora. Hal tersebut dilakukan untuk memberitahukan, mengenang kembali, dan meyakinkan orang-orang yang menghadiri ritual tersebut sehingga peceritaan kembali cerita Sanghiyang Prabu Borosngora menjadi penting dilakukan. Penceritaan cerita Sanghiyang Prabu Borosngora pada ritual upcara adat nyangku di malam hari sebelum ceramah maulid nabi, maupun di siang hari sebelum upacara pencucian benda pusaka dilakukan oleh yayasan Borosngora.
Upacara adat nyngaku membentuk identitas sosial (social identity) masyarakat Panjalu. Bagi keturunan Sanghiyang Prabu Borosngora, upacara adat nyangku dipergunakan untuk mengingat dan memelihara garis keturunan SPB pada setiap generasi mulai dari leluhur SPB hingga generasi sekarang. Pada bagian ini, SPB berfungsi sebagai penanda identitas sosial dan pengikat solidaritas sosial masyarakat Panjalu, baik yang tinggal di daerah Panjalu dan sekitarnya maupun yang merantau ke luar Panjalu.

Upacara adat nyangku memiliki fungsi pendidikan, yakni sebagai media pendidikan. Upacara adat nyangku dijadikan media untuk menyampaikan nilai-nilai tradisional dan kearifan lokal yang hidup di masyarakat Panjalu. Nilai-nilai yang dikembangkan adalah keimanan kepada Allah dan trisilas (silih asah, silih asih, dan silih asuh).

Upacara adat nyangku memberikan kontribusi signifikan untuk melegitimasi kesakralan wisata-religi di beberapa tempat ziarah di sekitar Panjalu, terutama Nusa Geude Situ Lengkong dan Bumi Alit sebagai tempat upacara adat dilaksanakan. Legitimasinya berupa sakralitas tempat dan waktu. Dari segi tempat, Nusa Gede Situ Lengkong dan Bumi Alit merupakan peninggalan orang suci setarap "wali" yakni Prabu Borosngora, yang diklaim seorang penyebar Islam pertama di tatar Pasundan atau Priangan. Dari segi waktu, bulan Maulid dinggap oleh masyarakat Panjalu sebgai bulan yang penuh berkat sehingga para peziarah pada bulan itu menjadi puncaknya.

Setiap hasil kebudayaan mempunyai fungsi, dan makna baik hasil kebudayaan tertulis, lisan, maupun upacara adat. Sebuah upcara adat sebagai hasil kebudayaan apapun bentuknya apabila difungsikan dalam suatu masyarakat, maka akan menghasilkan makna. Ratna (2010: 119) mengatakan, "Setiap aktivitas kebudayaan berfungsi atau difungsikan secara baik dengan sendirinya memiliki makna." Begitu juga dengan upacara adat nyangku di Panjalu sebagai hasil proses antarhubungan ideologi dengan masyarakat yang merupakan hubungan ekstrinsik mempunyai fungsi, dan makna.

Fungsi ritual pada upacara adat nyangku bagi masyarakat Panjalu termasuk pada fungsi manifest (nyata). Fungsi manifest adalah fungsi yang tampak, fungsi yang dikehendaki, dan disadari oleh masyarakat. Fungsi latent adalah 
fungsi terselubung, fungsi yang tidak dikehendaki, dan tidak disadari oleh masyarakat bersangkutan (Kaplan, 2002: 79). Fungsi-fungsi upacara adat yang termasuk fungsi manifest ialah fungsi pendidikan, politik, hiburan, dan ritual.

Upacara adat nyangku berdasarkan cerita Sanghiyang Prabu Borosngora (legenda keagamaan) dan fakta-fakta yang ada sangat dipercayai kebenarannya oleh masyarakat Panjalu. Legenda keagamaan adalah legenda orangorang suci seperti cerita para wali sanga di Jawa, mereka penyebar agama Islam pada waktu Islam mulai masuk pulau Jawa (Danandjaja, 2007: 68). Berdasarkan kepercayaan itu masyarakat Panjalu mengadakan upcara adat seperti upacara adat nyangku. Fungsi manifest penceritaan cerita $S P B$ pada acara ritual-ritual untuk meyakinkan, mengingatkan, dan memberitahukan kepada para pengunjung ritual sehingga mereka mau melakukan ritual-ritual itu.

Fungsi pendidikan upacara adat nyangku bagi masyarakat Panjalu termasuk pada fungsi manifest (nyata). Menurut Danandjaja (2007: 4), "Folklor mempunyai kegunaan (function) dalam kehiduapan bersama suatau kolektif. Cerita rakyat dan upacar adat misalnya mempunyai kegunaan sebagai alat pendidikan, pelipur lara, protes sosial, dan proyeksi keinginana terpendam." Upacara adat nyangku memiliki dua fungsi pendidikan, yakni sebagai materi dan media pendidikan. 1) Upacara adat nyangku dijadikan materi pendidikan nilai-nilai tradisional dan kearifan lokal. Nilai-nilai yang dikembangkan adalah keimanan kepada Allah, ketaatan terhadap orang tua, dan trisilas (silih asah, silih asih, dan silih asuh). 2) Upacara adat nyangku dijadikan media untuk menyampaikan nilai-nilai tradisional dan kearifan lokal yang hidup di masyarakat Panjalu.

Upacara adat nyangku dilaksanakan berdasarkan cerita Sanghiyang Prabu Borosngora. Cerita Sanghiyang Prabu Borosngora adalah cerita Islamisasi di kerajaan Panjalu dan tatar Periangan dengan tokohnya seorang anak yang sangat patuh dan taat kepada orang tuanya. Patuh dan taat kepada orang tua merupakan kewajiban bagi setiap anak. Hal tersebut sesuai dengan hadis, dan pendapat para ahli pendidikan sebagai berkut. . Hadis riwayat Ibnu Majah mengatakan,"Allah akan menimpakan kehancuran kepada orang yang durhaka kepada orang tuanya, baik dalam kehidupan maupun usahanya, sebagai siksaan buatnya. Dan, Allah
Makna dan Fungsi Upacara Adat Nyangku bagi Masyarakat Panjalu

Swt. akan menambahkan keberkahan umur sesorang bila ia berbakti kepada orang tuanya agar bertambah kebaktian dan kebajikannya. Yang dikatakan berbakti kepada orang tua adalah memberikan nafkah ketika mereka membutuhkan." Hadis tersebut, menyatakan Allah akan menimpakan kehancuran kepada orang yang durhaka kepada orang tuanya dan akan menambahkan keberkahan kepada orang yang berbakti kepadanya. Ritual upacara adat nyangku dilakukan oleh keturunan Prabuborosngora sebagai bentuk berbakti dan mengenang kembali atas jasa orang tua mereka dengan harapan amendapatkan berkat.

\section{PENUTUP}

\section{Simpulan}

Berdasarkan hasil analisis data dan pembahasan hasil analisis data penulis simpulkan, bahwa upacara adat nyangku memiliki empat fungsi, yakni fungsi ritual, fungsi pendidikan, fungsi sosial, dan fungsi wisata religi. Dari keempat fungsi tersebut, fungsi ritual lebih dominan daripada fungsifungsi lainnya.

Upacara adat nyangku berfungsi ritual karena upacara tersebut melahirkan eksistensi dan sakralitas ke berbagai tempat yang ada di Panjalu. Makam Nusa Gede sebagai tempat upacara adat disakralkan (dikeramatkan) karena terkait dengan peninggalan orang saleh dan sakti; air dari Situ Lengkong dikeramatkan karena dipercayai berasal dari air zamzam yang dibawa SPB dari Mekkah; dan upacara adat nyangku dipercayai akan memberikan berkah.

Upcara adat nyangku berfungsi pendidikan. Upacara adat nyangku memiliki fungsi pendidikan, yakni sebagai media pendidikan. Upacara adat nyangku dijadikan media untuk menyampaikan nilai-nilai tradisional dan kearifan lokal yang hidup di masyarakat Panjalu. Nilai-nilai yang dikembangkan adalah keimanan kepada Allah dan trisilas (silih asah, silih asih, dan silih asuh).

Upacara adat nyangku memiliki fungsi sebagai identitas sosial masyarakat Panjalu. Bagi keturunan SPB sebagai penanggung jawab upacara adat, upacara adat dipelihara untuk menegaskan atau melegitimasi identitas sosial mereka sebagai keturunan ningrat (atau darah biru) dan mereka merasa memiliki masa lalu yang jaya (agung). Bagi masyarakat pada umumnya, siapapun yang berasal dari Panjalu maka dianggap bersaudara. Persaudaraan ini 
sangat nampak melekat dipraktekkan oleh orang-orang Panjalu pada waktu melakukan upacara adat.

Selanjutnya upacara adat nyangku memiliki fungsi wisata religi (ziarah). Upacara adat nyangku digunakan sebagai penegasan (justifikasi) dan pengabsahan (legalisasi) berbagai tradisi yang ada, khususnya nyangku, samida, dan ziarah. Upacara adat tersebut menegaskan kesakralan dan eksotisme wisata religi (ziarah) ke Panjalu. Selama upacara tersebut terpelihara, maka tradisi wisata religi (ziarah) pun dapat tetap terpelihara. Upacara tersebut memiliki kontribusi cukup besar pada peningkatan aktivitas wisata di Panjalu, serta menumbuhkan pemberdayaan ekonomi masyarakat Panjalu. Di sadari atau tidak, masyarakat dan pemerintah Panjalu khususnya dan Ciamis umumnya telah memanfaatkan upacara tersebut sebagai salah satu daya tarik wisatawan untuk berkunjung ke Panjalu.

Upacara adat nyangku memiliki makna literal/historis, makna alegoris, makna tropologis/didaktis dan makna anagogis. Dari keempat makna tersebut, intensitasnya lebih tinggi pada makna literal/historis. Historisitas upacara adat nyangku terletak dari kesesuaian antara hal-hal yang diyakini masyarakat yang mendorong mereka melakukan upcara adat (terutama tokoh, tempat, dan peristiwa) dengan unsur-unsur kesejarahan, misalnya tokoh SPB dalam cerita yang dapat dirujuk dalam buku sejarah dan babad Panjalu, serta dapat dikaitkan dengan peninnggalan-peninggalan yang dapat digunakan untuk mengingat (yang masih ada).

Makna tropologis/didaktis yang terdapat dalam upacara adat nyangku cukup banyak, salah satunya adalah menyampaikan nilai-nilai tradisional dan kearifan lokal yang hidup di masyarakat Panjalu. Berdasarkan penafsiran hermeunetik (hermeunetic interpretation) upacara tersebut bermakna didaktis. Tandatanda narasi yang dimaknai dalam upacara tersebut pada umunya termasuk pada makna tropologis mengenai moral dan etika sesuai dengan budaya Sunda.

\section{Saran}

Setiap upacara adat merupakan warisan budaya para nenek moyang suatu kelompok masyarakat (folk) tertentu yang sangat berharga, begitu juga dengan upacara adat nyangku di Panjalu. Upaacara adat sebagai media komunikasi atau jembatan penghubung antara nenek moyang orang Panjalu dengan generasi masyarakat Panjalu sekarang dalam kerangka menyampaikan pesan-pesan berupa kearifan lokal (local wisdom). Berdasarkan hasil penelitian diketahui upacara adat nyangku berfungsi ritual dan bermakna historis.

Berdasarkan hasil-hasil penelitian di atas, penulis menyarankan kepada masyarakat Panjalu khususnya dan umumnya kepada semua orang yang mengikuti upacara adat tersebut agar mengaplikasikan fungsinya dan memahmai maknanya. Selanjutnya kepada semua pihak agar ikut menjaga dan memertahankan upacara adat tersebut agar tetap bertahan sampai pada generasi berikutnya.

Penulis berasumsi bahwa dalam upacara adat nyangku masih banyak masalah yang memerlukan penelitian. Untuk itu kepada peneliti selanjutnya agar meneliti upacara adat nyangku lebih luas dan lebih dalam lagi.

\section{DAFTAR SUMBER}

\section{Internet}

Karasuta, Nadia. 2014. Perilaku Sakral dan Profan pada Upacara Adat Rebo Wekasan di Desa Suci Kabupaten Gresik. HTTP://JMSOS.STUDENTJOURN AL.UB.AC.ID/INDEX.PHP/JMSOS /ARTICLE/VIEW/56 diunduh 05 Juli 2015, jam 10.00 WIB.

Khoiri, Madhan. 2009. Makna Simbol dan Pergeseran Nialai Tradisis Upcara Adat Rebo Pungkasan. Universitas Islam Negeri Sunan Kalijaga Yogyakarta (file:///C:/Users/Adab\%20BI/Downl oads/421-1170-2-PB\%20(1).pdf diunduh 05 Juli 2015, jam 10,30 WIB )

Mukharomah, Sayyidah. 2011. Memaknai Upacara Adat Tamat Sebagai Teks Kebudayaan Studi Kasus pada Masyarakat Desa Kemuja Kecamatan Mendo Barat Kabupaten 
Bangka. (http://karya-

ilmiah.um.ac.id/index.php/sejarah/ar ticle/view/738 diunduh 05 Juli 2015, jam 0,30 WIB.)

Nurmawati, Ela. 2010. Kajian Folklor Upacara Adat Saparan Pundhen Joko Kasihan di Desa Cacaban Kidul Kecamatan Bener Kabupaten Purworejo. (file:///C:/Users/Adab\%20BI/Downl oads/421-1170-2-PB\%20(1).pdf diunduh 06 Juli 2015, jam 08 WIB.)

Nurmayanti, Maya. 2014. Upacara Adat Nyuguh Kampung Kuta di Desa Karangpaningal Kecamatan Tambaksari Kabupaten Ciamis. (http://journal.unsil.ac.id/jurnalunsil1545-.html diunduh 06 Juli 2015, jam 09,10 WIB.)

\section{Buku}

Aquinas, Saint Thomas. 2004. Ceritical Theory since Plato. New York: Wordswart Publsihing, 3rd Edition

Bronner, Simon J. 2007. The Meaning of Folklore The Analytical Essay of Alan Dundes. Utah: Utah State University

Danandjaja, James. 2007. Folklor Indonesia. Jakarta: PT Pustaka Utama Grafiti
Makna dan Fungsi Upacara Adat Nyangku bagi Masyarakat Panjalu

Eagleton, Terry, 1976, Marxism and Literary Criticism, Routledge, London.

Jauhari, Heri. 2010. Panduan Penulisan Skripsi Teori dan Aplikasi. Bandung: Pustaka Setia

Kaplan, David dan Robert A. Manner. 2002. Teori Budaya. Yogyakarta: Pustaka Pelajar

Propp, Vladimir. 1997. Theory and History of Folklore. Minneapolis: University of Minnesota Press

Ratna, Nyoman Kutha. 2004. Teori, Metode, dan Teknik Penelitian Sastra. Yogyakarta: Pustaka Pelajar

2010. Sastra dan Cultural Studies Reperesentasi Fiksi dan Fakta. Yogyakarta: Pustaka Pelajar

Spradley, James P. 2006. Metode Etnografi. Yogyakarta: Tiara Wacana 